\title{
Nursing and the leading role of the user in the CAPS: a study from the constructionist perspective
}

\author{
A enfermagem e o protagonismo do usuário no CAPS: \\ um estudo na perspectiva construcionista \\ La enfermería y el protagonismo del usuario en el CAPS: un \\ estudio desde la perspectiva construccionista
}

\section{Hércules Rigoni Bossato Rosane Mara Pontes de Oliveirab Virginia Faria Damásio Dutra ${ }^{b}$ Cristina Maria Douat Loyolac}

\section{How to cite this article:} Bossato HR, Oliveira RMP, Dutra VFD, Loyola CMD. Nursing and the leading role of the user in the CAPS: a study from the constructionist perspective. Rev Gaúcha Enferm. 2021;42(spe):e20200082 doi: https://doi.org/10.1590/19831447.2021 .20200082
Universidade Federal do Rio de Janeiro (UFRJ) Campus Macaé Professor Aloísio Teixeira, Curso de Enfermagem e Obstetrícia. Macaé, Rio de Janeiro, Brasil.

' Universidade Federal do Rio de Janeiro (UFRJ), Escola de Enfermagem Anna Nery, Departamento de Enfermagem Médico-Cirúrgica. Rio de Janeiro, Rio de Janeiro, Brasil.

Universidade Ceuma, Curso de Mestrado Profissional em Gestão de Programas e Serviços de Saúde. São Luís, Maranhão, Brasil

\section{ABSTRACT}

Objective: To analyze the actions of the Nursing team to promote the leading role of the patient in the Psychosocial Rehabilitation Center.

Method: A qualitative study, with reference to Social Constructionism. The study was conducted with 16 members of the Nursing team in two CAPS in the city of Rio de Janeiro from September 2017 to January 2018. The data collected from interviews and observation were organized in the Nvivo Software and the thematic content was analyzed.

Results: The study analyzed leading care. This is constructed through creative communication, networking and the perception of the Nursing team as an "antenna".

Final considerations: The Nursing team does not reduce the users to the impossibilities of their psychiatric diagnoses, it uses creative communication and the construction of support networks in the territory. It constitutes itself as an antenna in care in psychosocial rehabilitation.

Keywords: Personal autonomy. Rehabilitation. Psychiatric nursing.

\section{RESUMO}

Objetivo: Analisar as ações da equipe de Enfermagem que promovem o protagonismo do usuário no Centro de Reabilitação Psicossocial.

Métodos: Estudo qualitativo, baseado no referencial do Construcionismo. Participaram do estudo 16 membros da equipe de enfermagem em dois serviços de saúde mental da cidade do Rio de Janeiro no período de setembro de 2017 a janeiro de 2018. Os dados coletados nas entrevistas e na observação foram organizados no Software Nvivo e analisados a partir do conteúdo temático.

Resultados: 0 estudo analisou que o cuidado protagonizador é construído através da comunicação criativa, do trabalho em rede e na percepção de que a equipe de Enfermagem funciona como uma antena.

Considerações finais: A equipe de enfermagem não reduz o usuário às impossibilidades de seu diagnóstico psiquiátrico, usa da comunicação criativa e construção de redes de apoio no território. Ela se constitui como uma antena no cuidado na reabilitação psicossocial.

Palavras-chave: Autonomia pessoal. Reabilitação. Enfermagem psiquiátrica.

\section{RESUMEN}

Objetivo: Analizar las acciones del equipo de Enfermería que promueven el protagonismo del usuario en el Centro de Rehabilitación Psicosocial.

Método: Estudio cualitativo, con referencia al construccionismo social. En el estudio participaron 16 integrantes del equipo de enfermería de dos CAPS de la ciudad de Río de Janeiro de septiembre de 2017 a enero de 2018. Los datos recopilados de las entrevistas y la observación se organizaron en el software Nvivo y se analizó el contenido temático.

Resultados: El estudio analizó los significados de la atención protagonista. Esta se construye a través de la comunicación creativa, de la creación de redes y de la percepción del equipo de enfermería como una antena.

Consideraciones finales: El equipo de enfermería no reduce al usuario a las imposibilidades de su diagnóstico psiquiátrico, utiliza la comunicación creativa y la construcción de redes de apoyo en el territorio. Se constituye como una antena en el cuidado de la rehabilitación psicosocial.

Palabras clave: Autonomía personal. Rehabilitación. Enfermería psiquiátrica. 


\section{口INTRODUCTION}

The present study addresses the actions produced by the Nursing team in a Psychosocial Care Center (Centro de Atenção Psicossocial, CAPS) to promote the leading role of the user in the light of Social Constructionism. The constructionist perspective guides an investigation that is concerned with the explanation of the processes through which people describe, explain, argue, and construct the notions of themselves and of the world in which they live, considering a certain historical moment and during social relations ${ }^{(1)}$.

The paradigm change in the field of mental health assumes a transformation, in addition to a technical dimension (review of the care practices), a cultural dimension, in defense of a change in the social value of people, which allows individuals to experience and participate in community life. Therefore, the intention is that people develop peculiar ways of being in the world and of experiencing their sufferings, joys, frustrations, victories, and insecurities ${ }^{(2)}$. It stands out as a problem of the study that the Nursing actions in mental health still need to be implemented as therapeutic and with an approach in psychosocial care and not only in plans and prescriptive procedures that devalue the autonomy of the person who needs the mental health service.

Psychosocial rehabilitation is crossed by several challenges, one of which is the promotion of the individual's citizenship, mediated both by promoting the role of the patient and by maintaining autonomy in the face of therapeutic proposals. Rehabilitation itself is a vision, it is being able to be, it is the reconstruction of the citizen's social contractuality, which involves the home or habitat and social life, including exchange, learning, and work ${ }^{(3)}$.

In this context, the Nursing team is an important potential in the rehabilitation scenario, since Nursing care based on singularity is fundamental for the psychotic person, since it allows for listening, welcoming, bonding, co-responsibility, and emotional support. Furthermore, the participation of this team in the Singular Therapeutic Project can favor a return to the condition of individual for the user ${ }^{(4)}$.

Nursing work in the CAPS is essential in this articulation, since Nursing works full time in daily care. It is the only team of health professionals who works 24 hours with the user. In this context, the study raised the following question: How does the Nursing team produce actions to promote the leading role of the user in Psychosocial Rehabilitation? The objective is to analyze the actions of the Nursing team that promote the leading role of the user in CAPS III.
The study is justified by the pioneering role of Nursing in the comprehensive care of the user and in the valorization of the person assisted in this space, even though in the past the performance of Nursing has been marked by the institutionalization of asylum rules, focused on disease and medicalization ${ }^{(5-7)}$. After the Brazilian Psychiatric Reform and the implementation of the National Humanization Policy, the Nursing team has been developing leadership in the management of daily actions that value the subjectivity of the person and contributing to their social inclusion and autonomy ${ }^{(8-9)}$.

This study is relevant since it produces knowledge for a know-how for the Nursing team, in order to build therapeutic devices in promoting the leading role of the user, in order to offer a possibility of creative production in Nursing care in Psychosocial Rehabilitation aligned with advances in the Psychiatric Reform.

It is worth mentioning that the present article presents data analyzed from a doctoral thesis linked to the Center for Study and Research in Psychiatric Nursing and Mental Health at the Anna Nery School of Nursing of the Federal University of Rio de Janeiro.

\section{$\square$ METHOD}

This is a descriptive-exploratory study with a qualitative approach. The Equator: SRQR-Standards for Reporting Qualitative Research instrument ${ }^{(10)}$ was used to design the study, in order to guide the study methodology.

The research scenario took place in two Type III Psychosocial Care Centers (CAPS), located in the city of Rio de Janeiro. It is worth mentioning that the municipality has a universe of four CAPS III. The choice of locations was made randomly, according to the interest and availability of the participants. The period of data collection, both from participant observation and from unstructured interviews, was carried out from September 2017 to January 2018. The research participants were nurses and Nursing technicians working in these spaces. Participants with less than six months of experience in the scenario were excluded, and nurses and technicians with a time of six months or more, with a permanent or temporary employment contract, were included. The indication of the respective length of service is due to the factor most likely to develop a bond with the users, the team, and therapeutic projects.

Data collection was carried out by means of participant observation and non-structured interviews. A total of 16 participants were interviewed, including nurses and Nursing technicians. They answered the non-structured interview 
based on a checklist elaborated by the researchers. This guide has thematic axes with open questions based on the assumptions of the Brazilian Psychiatric Reform, the ethical conduct of the Nursing team, the work process and the actions that provide and/or collaborate with the autonomy and citizenship of the users. The axis which guided the conversations in the interviews were the following: 1) actions for leading role; 2) participation in the unique therapeutic project; 3) perception of Nursing care; 4) recognition of patients' rights and citizenship; 5) support network and assistance network; 6) communication mechanisms for the patients' knowledge about mental illness, psychological distress, and treatment; 7) personal work experience in the CAPS.

The interviews and the recording of the observation were stopped after exhaustiveness of the communication was identified through the repetition of themes in the initial phase of the analysis in the treatment of the data. Participant observation totaled 112 hours of registration and each interview lasted a mean of one hour. They were recorded on an $\mathrm{mp} 3$ audio recorder and the observation was recorded in the researcher's field diary. These interviews were returned to the respective study participants, via personal email, for approval of the transcribed content.

It is worth pointing out that the researchers do not have a working relationship with the study scenarios. Only one researcher was present in data collection and, before starting the research, he participated in the meetings of the CAPS III team to present the study to all the members of the CAPS. In this way, the study was presented both to the participants (nurses and technicians) and to non-participants of the study (managers, other professionals, and users), in order to communicate the entire service group about the realization of the study with Nursing staff. The researcher who performed the collection also prepared the respective data transcripts. The other researchers participated in the organization of the data, analysis, final report, and feedback to the participants.

The data were analyzed in the light of Kenneth J. Gergen's Social Constructivism ${ }^{(1)}$. To point out the actions of the Nursing team that prove the leading role of the user in the CAPS III, the study was based on a relational theory linked to the practice that is anchored in the paradigm of postmodern social construction(1). In Brazil, several constructionism scholars argue that studies using relational theories make more sense to the Unified Health System ${ }^{(11)}$.

In Gergen's words: "Social Constructivism is a way of being in the world". Consequently, when adopting the constructionist referential, it is necessary to be based on the theoretical descriptions that are often part of our daily experiences to point out a social reality. Then, meaning is created in the context of the relationships ${ }^{(1)}$.

Thus, in the constructionist perspective," what is real, rational and good" is presented ${ }^{(1)}$ in the relationships between the user of CAPS III and the Nursing team to promote the leading role of the person in psychosocial care in that space.

In the data analysis, the technique that Spink called map of association of ideas and production of meaning of Social Constructionism was used. This technical approach is based on Social Constructionism through the analysis of language, of speech, and of content for the production of meanings and preserving the present and lived content and time of the speech ${ }^{(11)}$.

Thematic content analysis of the interviewees' testimonies was carried out, as well as of the observation records using the technique of the map of association of ideas and production of meaning. "The construction of maps begins with the definition of general categories, of a thematic nature, which reflect, above all, the objectives of the research"(11:84).

For organizing and coding the data, the N Vivo Pro 12 software was used in the study. This is a device for thematic content analysis for qualitative health research, which allows creating categories, coding, filtering, conducting searches, and questioning the data, in order to answer the questions of a scientific study ${ }^{(12)}$.

Data encoding in the software was performed by pairs. After organizing and coding the data, thematic content analysis was performed using the map of association of ideas and production of meaning. Both the data from the interview transcripts and the observation record were also analyzed by pairs.

The ethical aspects of research with human beings, as recommended by the National Health Council, were complied with, in accordance with Resolutions No. 466/2012 and No. 510/2016. The research project was submitted to Plataforma Brasil, being approved by the Research Ethics Committees of the Anna Nery School of Nursing - São Francisco de Assis Teaching Hospital and the Rio de Janeiro Municipal Health Secretariat under CAAE No.: 68003617.2.0000.5238, opinion No. 2,117,532.

\section{RESULTS AND DISCUSSION}

It is emphasized that the intentionality of the present work has a militant construction influenced by the context of the challenges related to the Brazilian Psychiatric Reform movement, since the intentions are consolidated in the reflections and actions for the most concrete changes on the performance of Psychiatric Nursing and in mental health in the ethical dimension of its care clinic. 
The actions of the Nursing team in promoting the role of the user in CAPS III mark a sense that points to the leading care in negotiation with the territory. The treatment of the data resulted in three thematic categories: 1) creative communication; 2) networking; and 3) The Nursing team as an antenna.

\section{Creative communication}

Creative communication was observed by the researchers as a care tool to dialog with the users about their illness, psychological suffering, treatment, and general guidelines on health and citizenship. It is a resource used in Nursing to produce effects on language in order to favor exchange and mental health care in a horizontal relationship with the patient:

We elaborate methods so that this care is not lost, one of the examples is that you establish, create a document that speaks through language: a sun, a moon, a cup of coffee indicate the times. (E3)

I realized that the user identified the medication by color and not by name [...] he even knew what the effect of the medication was, but he did not know what medication he was taking [...] I saw that it was necessary for him to know what he was taking. (E4)

We set up a package here like morning, afternoon, night, which is the medication schedule [...] so, I think this is a good part of Nursing that we show them the medication and their leading role in taking it. (E16)

The Nursing team invests in the user in order to manage drug therapy and remains on the correct use of drug therapy, and stays in readiness to assist in this handling, using symbolic language (figures with sun, moon, coffee to express the schedules) when needed. In addition, it establishes a creative language about medication schedules and recognizes the need to guide the users on the purposes of using the medications.

In the communicative act, there is transmission of the message (verbal and non-verbal) from the sender in order to send a message to the receiver (individuals or groups), so as to obtain a response, a channel of dialog, an idea, thus establishing a link with the communicative process for the transmission of a message ${ }^{(1)}$. "Effective communication, therefore, is intertwined for mutual understanding, cooperation of actors, comprehension of individual contexts, and the positioning of the receiver in the face of the speech act"(13-14).

For Constructionism "one thing is to generate attractive ideas, but the important question is to check if there is a productive relationship between words and our ways of life"(1). The Nursing team informs, discusses, and provokes the possibility for the user to negotiate the drug prescription. However, the team makes it clear that the user of the CAPS needs to be prepared to express such a negotiation:

When we go to administer medication, we reinforce the leading role of the user. 'Look, you are taking this medication due to that reason.... For such conditions... Until you get organized and then the doctor will review your medication, [...] depending, you can simply stop, or reduce this medication [...] As you get organized, you can negotiate with the doctor. (E11)

Now if the patient, comes here and says: "I will not take", I do not force him. So, you will go to your doctor, talk to him and tell him why you don't want to take this medication. So, I consider that he has a negotiating stake on the medication. (E13)

The communication of the Nursing team is crossed by a clinical conduct to bring the individual to meet the therapy, tracing creative mechanisms for the care process ${ }^{(14)}$. Thus, the team invests leading care in a language and communication close to the user:

We have a chart of possible activities. We describe some In informal conversations, it is a very important thing because care appears much more than in the office. There, in the conversation you realize, you know... a little of how is that person's daily life, if he's using drugs, if he's not, if he's going out, it's a little bit there in that very informal conversation, usually smoking a cigarette that these things in life start to appear, and this is also a product of work. (E14)

It was evidenced by the participant observation that the Nursing team builds mechanisms to facilitate and instruct the user's comprehension of the therapeutic procedures. The Nursing team uses creative means to produce a constructionist dialog, as it takes into account the local reality and the social context of the individual, producing resignification through shared language and relativized in relation to the mental disorder and/or psychological suffering: 
We work, work more with other figures of speech in fact. With drawings, with body expression, with the speech itself, we memorize. Ah! Do you want to create a poem and can't write? You can talk, we record it, we record a video, or a pen drive, keep it for him to hear. (E2)

We from the team try not to stay too much in the technical term, we try to stay more in their jargon of the community itself, you know? So, like this, we have greater ease than other teams. (E5)

For Social Constructivism: "Words help to maintain these life forms, while life forms give meaning to the words" ${ }^{\prime \prime 1: 27)}$. In this way, the CAPS Nursing team reframes its form of creative communication through listening closer to the user's context, in order to provide constructionist dialogs.

This creative communication to instruct is related to a constructionist perspective because: "It is the truth in operation that tends to favor forms of dialog from which new realities and new values can emerge" ${ }^{\prime \prime(1)}$, which can be observed in:

We from the mental health work a lot with bets [...] we invest in that bet, if it works then it is great, if it doesn't work, we will try another way. (E7)

[...] I gradually resignify it with him and naturalize it subjectively and I don't bring the disorder to him [...] I don't do any of this like the doctor does. (E15)

Thus, it is in the meeting between the Nursing team and the user of the CAPS that creative communication takes place, meetings ruled by an intersubjectivity, between the professional's knowledge and the user's experience."Nurses point out that there are no truths or prior knowledge, because it is in daily practices that decisions are agreed upon"(8:7).

In summary, creative communication is an action of the Nursing team to promote the leading role of the user. It is evidenced when Nursing launches mechanisms to dialog and negotiate with the madness and subjectivity of each user. It is necessary to mediate with the person's territorialities and, thus, to know, understand, and value the individual's socio-cultural context and history, so as to promote care actions.

\section{Networking}

The Nursing actions to promote the leading role of the user in the CAPS are related to the way of building care networks at work focused on territorial actions.
There is a need for nurses to institute a matrix support routine, in order to integrate a network to share experiences and dialogs with the demands of mental health in primary care. A care network is defined by the social environment, which carries out health care actions integrated into the territory, such as: school, home, church, club, cinema, associations ${ }^{(15)}$. Such integration in the territory is identified in the following descriptions:

We build the work together with the basic health units, to not focus care on the CAPS, to dissolve this care, because there is still an idea that the crazy person has to be seen from head to toe inside the hospice. So, we try to deconstruct this logic in the territory at all times, it is a daily job. (E1)

We try to place them, always insert them and we also place ourselves to be in that space together with them, more and more within the care of the CAPS, which is also building an acceptance and less discriminatory space with society. (E2)

[...] This connection, this union of basic health with mental health is very important, especially now that they have become the gateway and such. And then, we have a little more and better access to the family clinic. (E11)

We are always in contact with them, because we even seek in some of the most dangerous territories to do home visits with the Community Health Agent. (E12)

For Social Constructionism, the creation of networks and interconnections produces an effect of what is truly good for the collective."The challenge is not to find the best way, but to create types of relationships through which the future can be built in a more collaborative manner."(1:31). The care network is an essential device for Nursing to produce actions for the leading role of the user in the CAPS. This web goes beyond the health services, it is a mechanism that provides social and therapeutic exchanges, in order to work on possibilities for promoting health and citizenship to fit in life:

Always try to work on autonomy. [...], we get closer at some moments when we need to, let him walk a little more, when we think he is doing well. (E2)

[...] We started to identify the potential of these people, I'm talking about people who, until then, did not produce anything and we managed to insert them into the job market, that was really cool, then you see the leading 
role of the person being able to work, being able to earn their own money, being able to remove that label. (E3)

We confirm this speech in a research study carried out to list clinical Nursing care in mental health, in which care was identified and characterized as having integrality, based on a network, interdisciplinarity, intersectoriality, welcoming, listening, notion of territory, psychosocial rehabilitation, health education tools and workshops, experience, and a recognition of subjectivity to promote the $\mathrm{clinic}^{(16)}$.

Our interviewees point out that the Nursing actions for networking go beyond the CAPS walls, and create mechanisms for social exchanges beyond the institutional figure of the service, and the actions are configured as a territorial movement beyond the walls:

\section{My care practices are not medicated, the issue of talking to many patients here who have a great need to be talking about themselves. (E11)}

I think that the less time the guy is in the CAPS, I find it more interesting, the idea is that he can be in other spaces, but there are people who need to be here every day. (E14) I understand that the CAPS, as a physical structure, is just a reference, because the CAPS is us, the team composed of all the mental health professionals, I understand that the CAPS are mobile, because we can circulate in the territories and share the care provided, doing it with the network. (E15)

The CAPS professionals, consequently, a large part of the nurses, highlighted that their work activities are not only internal, but mainly external, since in the work process it is necessary to create devices that mediate social inclusion, autonomy, and citizenship for users who suffered exclusion processes ${ }^{(6-8)}$.

A study carried out in the Nordic countries addresses the evidence of the positive impact of making and meeting friends, family, relatives or acquaintances, on the significantly higher functioning on the autonomy scale -Global Assessment of Functioning-compared to interviewees who reported rarely or never meeting friends, family, relatives or acquaintances ${ }^{(17)}$.

As recorded in the participant observation, we found a Nursing team with care actions focused on the territory to build care networks, a team committed to promoting the individual's health and where the psychiatric condition and its subjective difficulties did not encapsulate the potential of the individual, so that it was still possible to produce health for rehabilitation. Finally, it is considered that the care network is decisive on the product based on leading care.
It is worth mentioning that the actions contained in the leading role do not constitute a practice that involves only the Nursing team, but also a wide care network. To this end, Nursing can facilitate and streamline the organization of a practice that involves networking, activating actors and contexts beyond the territory in which the person lives and, thus, promoting social exchanges beyond the CAPS.

\section{The Nursing team as an antenna}

According to the Houaiss dictionary of the Portuguese language, the figurative meaning of the word "antenna" means the sensitivity to capture a medium of information. It is a channel to receive or disseminate information ${ }^{(18)}$.

The Nursing team as an antenna works as a primordial energy transmission guide for quality communication available to promote the person's role in psychosocial rehabilitation. A kind of possibility catcher, but always acting as a secretary of that person's desire.

In this sense, Nursing as an antenna is a team that is available to be attentive to the needs of the user of the CAPS, and provides leading care. A tuned team is an attentive, available team that aggregates the strength of everyone in one movement and intervenes in the care provided.

Nursing as an antenna is a fundamental link in the mediation of the crisis. It produces a field of care that spreads among all. Thus, they are available to exercise leading care.

In a study on Nursing care in the context of Psychiatry, the authors show that the care routine obeys the patient's will and not the nurse's. Thus, we can say that the Psychiatric Nursing routine is established by the patient and this becomes, for us, the immediate meaning of helping to manage madness ${ }^{(19)}$.

Therefore, the Nursing team as an antenna provides actions based on the availability of care. Such phenomenon is traced through the readiness with which Nursing is launched in the care actions with the other, in an integral manner:

We can handle this outbreak, right... Many times, making ourselves available to making him take care of something, taking the focus off any issue that he has about this agitation and that he cannot bring to us, he cannot talk about it. (E10)

[...] Having to reinsert the individual into society is, therefore, a very difficult job... until you convince the other, convince society that he is still capable of living in that society. (E11)

[...] These more specific functions of Nursing, so I think we promote this leading role of the user when we are together. (E14) 
The availability of Nursing care in the CAPS is elaborated through delivery, empathy, and commitment with responsibility for knowledge/doing centered on the individual(1-8). Nursing as an antenna tends to mediate its clinic in care and daily actions focused on the individual's life needs, with a look beyond the limitations of the mental illness, and that reaches a holistic view of the individual.

Thus, staying tuned is a movement of the Nursing team that makes itself available in the field of everyday relationships, to welcome and care for the individuals so that they have the competence to assume the leading role in life.

Social Constructionism favors the replacement of the individual by the relationship, that is, it is in the relationship that truth, dialog, and the constructionist act are built ${ }^{(1)}$. In this sense, there is only availability for the act of caring when the team places itself as an antenna and this posture is a link for leading care.

The study participants approach the Nursing phenomenon as an antenna, which provides availability for psychiatric and mental health Nursing care, in order to promote the leading role of the user through leading care:

I think that what really guides us is the bond, because they have a great bond with the Nursing team. Even though I am not the reference of a case, sometimes the patient comes and looks for me. (E1)

[...] we build this whole process with him to restore him and make him a person who can return to society a little better. (E6)

Stopping, listening to the individual as a whole, from there giving a voice to the individual, who is in need at the moment, is one of the biggest pillars, not only the medication issue of dressing, no. I think it goes far beyond that, care. (E11)

Nursing is always right on the front line [...]. So, when he arrives, he immediately comes to Nursing. So, I try to be looking at them to see if they have any injury, anything, see if they are really well clinically. (E12)

$[. .$.$] The first thing I do is read about them, most of them$ I already know, but there is one that I don't know so I arrive and I already try to talk. (E13)

It is worth mentioning that the Nursing team places itself as an available antenna to receive and capture the demands and needs of the user. Consequently, it is Nursing that places itself "on the front line" in the agitation and crisis situations:

The crisis within this service, as it is a structure that has no window, the issue of smoking is something that we have to go outside with the patient to smoke in a moment of crisis of body restraint, if we do not take him to smoke the patient becomes more agitated. (E1)

At CAPS III, we work with the patient, work hand-to-hand with him, even if he is in crisis, it is a totally different care. He sees you as a family member and not as part of the Nursing team. (E8)

I like working on the organization of the device much more on the day of my work as a crisis mediator. For this reason, I stay in this circulation between coexistence, corridor and then I stay there as an antenna capturing things. (E15)

It is important to highlight that the Nursing team as an antenna is configured by the availability that is capable of welcoming the user's autonomy and of promoting his leading role through leading care:

Always try to work on autonomy, whoever can, we will provide an orientation, you have to look for such a place, call, call and etc... we watch the progress, then we get closer at some moments when we need to, let him walk a little more, when we think he is doing well. (E3)

His therapeutic project is basically to leave the residence and come here to the CAPS with me, we stay here for a while, and then I accompany him to a fair that has what is good for him [...], because I think that he has worked with it, I don't know, but it has an outline in the matter of his life. (E4)

We observed that in welcoming a spontaneous demand from an older adult female user, the nurse and a Nursing technician developed the listening process. The user was very agitated and said that she would commit suicide. The professionals allowed her to talk about the issue of suicide. Immediately after, they asked questions about her life story. And she told parts of it. At the end of the welcoming, we verified that the user was more relaxed and satisfied with the service, and also said that the CAPS was her second home.

This record illustrates that the action of Nursing as an antenna is to have availability for care at the CAPS. It is necessary to build a Nursing clinic in mental and psychiatric health, based on the tools of listening, bonding, welcoming, co-responsibility, and matrix support. These instruments are essential for Nursing to be tuned with the users' needs and for it to be available for leading care.

The concept of Nursing as an antenna concerns the ability of the Nursing team to capture care, to feel that there is a demand, recognizing crisis situations, promoting life projects, 
beyond the CAPS walls, in mediation with family members and in a therapy that values the user's rights and citizenship.

\section{finAl CONSIDERATIONS}

Pointing out the Nursing actions to promote the leading role of the person using the Psychosocial Care Center made it possible to outline dimensions of a political, ethical, and clinical triad for leading care.

The study points out how the Nursing team produces actions to promote the role of the user in Psychosocial Rehabilitation. Such actions operate mainly through creative communication and through networking. All of this mediated by a Nursing team that perceives itself as an available antenna for psychosocial actions and in negotiations with the assisted person's territory. Thus, leading care in this scenario is evident.

In short, there are punctual advances by the Nursing team in promoting actions that go beyond the administrative issue in the Psychosocial Care Centers. The Nursing team translates time into concrete things like the sun and the moon, monitors the use of medication with attention to autonomy; uses the importance of the apparent informality of the meetings to discuss leading care; uses different forms of language and recordings (video, drawing); does not reduce the users to the impossibilities of their psychiatric diagnoses and works in the construction of support networks in the territory; and, mainly, it constitutes the care antenna, a concept that means perceiving, receiving, and integrating the best care offered by each team member.

The work brings contributions on mechanisms and tool constructions in the social field for the assistance of the Nursing Team in the setting of Psychosocial Rehabilitation. For the teaching of Psychiatric Nursing, it provides new horizons for working with innovative categories of the Nursing team in the therapeutic process and, for research, it points to possibilities of tracing advances and challenges in Nursing in the context of the Brazilian Psychiatric Reform and of the Humanization of Care Policy.

The study points out a limitation regarding the scope of data collection in various psychosocial care settings, as it presents data from two Type III Psychosocial Care Centers, that is, the study was not developed in other contexts of mental health care, as well as other types of Psychosocial Care Centers. In addition, the refusal of one of the fields and the impossibility of collecting data in another, due to aspects related to territorial insecurity due to the confrontation between the military policy and drug trafficking, was another limiting factor in relation to the expansion of data collection.

\section{REFERENCES}

1. Gergen KJ, Gergen M. Construcionismo social: um convite ao diálogo. Rio de Janeiro: Instituto Noos; 2010.

2. Ferreira TPS, Sampaio J, Souza ACN, Oliveira DL, Gomes LB. Care production in Mental Health: the challenges beyond institutional walls. Interface (Botucatu). 2017;21(61):373-84. doi: https://doi.org/10.1590/1807-57622016.0139

3. Saraceno B. Ações dos serviços territoriais para inclusão social. In: Barros $S$, Batista LE, Santos JC, editores. Saúde mental e reabilitação psicossocial: avanços e desafios nos 15 anos da Lei 10.2016. Uberlândia: Navegando Publicações; 2019. p.125-41.

4. Pintor LA, Toledo VP, Garcia APRF. Nursing care based on the perspective of the subject of the unconscious and its contribution to the Singular Therapeutic Project. Rev Eletrôn Saúde Mental Álcool Drog. 2018; 4(1):20-2. doi: https:// doi.org/10.11606/issn.1806-6976.smad.2018.000395

5. Oliveira LC, Silva AR, Medeiros MN, Queiroz JC, Guimarães J. Humanized care: discovering the possibilities in the practice of nursing in mental health. Rev Pesqui Cuid Fundam Online. 2015;7(1):1174-82. doi: https://doi. org/10.9789/2175-5361.2015.v7i1.1774-1782

6. Amarante P, Nunes MO. Psychiatric reform in the SUS and the struggle for a society without asylums. Ciênc Saúde Colet. 2018;23(6):2067-74. doi: https:// doi.org/10.1590/141381232018236.07082018

7. Bruggmann MS, Souza AlJ, Costa E, Schneider DG, Schmitz EL, Mazera MS. Development of a collective knowledge for implementation of the nursing process in a specialized psychiatric hospital. Rev Min Enferm. 2019;23:e-1270. doi: https://doi.org/10.5935/1415-2762.20190118

8. Dutra VFD, Bossato HB, Oliveira RMP. Mediating autonomy: an essential care practice in mental health. Esc Anna Nery 2017;21(3):e20160284. doi: https:// doi.org/10.1590/2177-9465-EAN-2016-0284

9. Maftum MA, Silva AGS, Borba LO, Brusamarello T, Czarnobay J. Changes in professional practice in the mental health area against Brazilian psychiatric reform in the vision of the nursing team. Rev Pesqui Cuid Fundam online. 2017;9(2):309-14. doi: https://doi.org/10.9789/2175-5361.2017.v9i2.309-314

10. O'Brien BC, Harris IB, Beckman TJ, Reed DA, Cook DA. Standards for reporting qualitative research: a synthesis of recomendations. Acad Med. 2014;89(9):1245-51. doi: https://doi.org/10.1097/ACM.0000000000000388

11. Spink MJ, Lima H. Rigor e visibilidade. In:Spink MJ, editor. Práticas Discursivas e produção de sentidos no cotidiano. Rio de Janeiro: Centro Edelstein de Pesquisas Sociais; 2013.

12. QRS. Nvivo. Versão Nvivo Pro 12 for Windows 2018 [Software]. 2017 [cited 2020 Jan 25] Available from: http://www.qsrinternational.com/nvivo-portuguese

13. Alves KYA, Bezerril MS, Salvador PTCO, Feijão AR, Santos VEP. Effective communication in nursing in the light of Jürgen Habermas. Rev Min Enferm. 2018;22:e-147. doi: https://doi.org/10.5935/1415-2762.20180078

14. Soares IP, Lima EMM, Santos ACM, Ferreira CB. How do i talk to you? The communication of the nurse with the deaf user. Rev Baiana Enferm. 2018;32:e25978. doi: https://doi.org/10.18471/rbe.v32.25978

15. Oliveira GC, Schneider JF, Pinho LB, Camatta MW, Nasi C, Guimarães AN, Torres MEL. Matrix support in mental health in primary care: the vision of supporters and nurses. Rev Gaúcha Enferm. 2020;41(esp):e20190081. doi: https://doi. org/10.1590/1983-1447.2020.20190081 
16. Azevedo DM, Silva GWS, Miranda FAN, Bessa MS, Lins SLF, Costa JE. Perceptions of health professionals on social inclusion in a Psychosocial Care Center. Rev Rene. 2019;20:e33537. doi: https://doi. org/10.15253/2175-6783.20192033537

17. Levinsson $H$, Kjellin L, Östman M. Autonomy and severe mental illness: the relationship between social network and functioning. S0J Nur Health Care. 2016; 2(2):1-5. doi: https://doi.org/10.15226/2471-6529/2/2/00118
18. Houaiss A. Dicionário Houaiss da língua portuguesa. Rio de Janeiro: Moderna; 2020.

19. Oliveira RMP, Alves M, Porto IS, Cavalcanti PCS. The psychiatrical nursing clinic and its new care technologies. J Res: Fundam Care online. 2016;8(1):3922-34. doi: https://doi.org/10.9789/2175-5361.2016.v8i1.3922-3934

\section{- Corresponding author:}

Hércules Rigoni Bossato

E-mail: profhercules@ufrj.br

\section{Associate editor:}

Dagmar Elaine Kaiser 